\title{
Local signals in stem cell-based bone marrow regeneration
}

Wei Han, Yan Yu, Xin Yuan Liu

Cell Research (2006) 16:328. doi:10.1038/sj.cr.7310042; published online 16 March 2006

Correction to: Cell Research (2006) 16:189-195. doi:10.1038/sj.cr.7310026; published online 13 February 2006

There is an error in Table 3. Tgf 33 should belong to Hematopoietic growth factors. This has now been corrected online and in the current print issue.

Table 3 Partial list of genes encoding secreted proteins expressed by HSCs

\begin{tabular}{ll}
\hline Growth factors & $\begin{array}{l}\text { Agpt, Btc, Ereg, Fgf15, Fgf18, Fgf3, Fgf7, Fgf8, } \\
\text { Pdgfc, Vegfa, Vegfb }\end{array}$ \\
Cytokines & $\begin{array}{l}\text { Gdf8, Ifna5, I11f6, I14, Scgb3a1, Scya19, } \\
\text { Scyb14 }\end{array}$ \\
$\begin{array}{l}\text { Hematopoietic } \\
\text { growth factors }\end{array}$ & Tgf 33 \\
Morphogens & Agr2, Bmp2, Bmp5, Bmp8a, Dl11, Jag2, Wnt1, \\
& Wnt6, Wnt10a, Wnt11 \\
\hline
\end{tabular}

